\title{
THE PROJECT "EN ROUTE OF BULGARIAN GARDENERS" - IDEAS, RESULTS, PERSPECTIVES
}

lliya Valev', Galya Chohadzhieva², Monika Tyutyunkova³,

ilia_valev85@mail.bg, galja_choh@abv.bg, monmar55@gmail.com

${ }^{1}$ Regional Museum of History - Veliko Tarnovo, Bulgaria

2 Museum of History - Gorna Oryahovitsa, Bulgaria

3 Research Institute of the Bulgarians in Hungary, Bulgaria

\begin{abstract}
The Bulgarian gardeners-abroad are no doubt one of the serious factors in the enrichment of the culturalhistorical heritage in Europe during XIX and XX-th century. This historical fact is not known and accepted enough in a larger range. Because of that, at the initiative of Researching Institute of Bulgarians in Hungary at Bulgarian republic self-government in Hungary, with the basic partnership of the Regional Museum of History - Veliko Tarnovo there was organized a researching team including specialists of different scientific, cultural and educational institutions who have developed a project for making a cultural route "En route of Bulgarian gardeners". The article discusses the ideas of the project, the results achieved so far and the possible perspectives for its development..
\end{abstract}

Keywords: Cultural Routes, European Council, Gardeners-Abroad, European Identity, Cultural Heritage.

\section{ПРОЕКТЬТ "ПО ПЪТЯ НА БЪАГАРСКИТЕ ГРААИНАРИ" - ИАЕИ, РЕЗУАТАТИ, ПЕРСПЕКТИВИ}

А-р Илия Вълев' , Галя Чохалжиева 2 , Моника Тютюнкова ${ }^{3}$

ІРегионален исторически музей - Велико Търново

2Исторически музей - Горна Оряховица

ЗИзслеАователски институт на българите в Унгария

Резюме: Българските градинари-гурбетчии безспорно са еАин от сериозните фоктори в обогатяването на културно-историческото наслеАство в Европа през XIX и XX век. Този исторически фракт обаче не е Аостатьчно познат и признат в по-широк мащаб. Ето защо по инициатива на 
ИзслеАователския институт на българите в Унгария при Българското републиканско самоуправление в Унгария, с основното партньорство на Регионален исторически музей - Велико Търново, се сорормира изследователски екип, вкАючващ специалисти от различни научни, културни и образователни институции, който разработи проект за съзАаването на културен маршрут "По пътя на българските градинари". Статията разглежАа илеите на проекта, постигнатите Ао този момент резултати и възможните перспективи за неговото развитие.

КАючови Ауми: културни маршрути, Съвет на Европа, градинари-гурбетчии, европейска иАентичност, културно HaC^еАСтво

Известно е, че традиционното гурбетчийство като явление с обществен, социален, културен и икономически характер е резултат от Аипсата или неАостига на среАства и възможности за препитание. Именно това кара хиляли хора да изоставят семейство, Аеца, ролители и $\Delta а$ трьгнат по широкия свят, за $\Delta а$ тьрсят работа. Но както в миналото, така и Анес, в резултат на миграциите, освен осигуряване на парични средства в ^ичен план и натрупване на трудов опит, се получава и широк културен обмен, който прави гурбетчиите еАин от найсериозните фоктори за обогатяване на културно-историческото наслелство на всеки народ. Безспорен фоворит в това отношение за българите през XIX и XX в. са градинарите-гурбетчии'.

\footnotetext{
${ }^{1}$ На българските градинари гурбетчии и на техния принос за развитието на европейската култура и селскостопанска практика са посветени много изследвания: Гинчев, Ц. Няколко Ауми от историята на нашето граАинарство (бахчованАжильк) и за уреАбата на градината. В: Труа. Кн. І. Велико Търново, 1887, (Ginchev, 1887); Гешов, Ив. Нашите градинарски Аружества. - В: Периодическо списание на бьлгарското книжовно Аружество. Гол. VI, Кн. XXVII. Средец, 1888, (Geshov, 1888); Сираков, М. Градинарите от Търновско в странство (студия). В. Тьрново, 1922, (Sirakov, 1922); Чангова-Менихарт, П. ПоА сльнцето на Унгария: очерк за стопанската Аейност на българските градинари (1720 - 1980). Соория, 1989, (Changova-Menihart, 1989); Гюров, АА. ЕАинадесетвековно българско присьствие в Унгария. Будапеща, 2001, (Gyurov, 2001); Ганева-Райчева, В. Българите в Унгария - проблеми на културната илентичност. София, 2004, (Ganeva-Raycheva, 2004); Симеонова-Харгитаине, Р. Гралинарската култура и дейност на българските градинари в Унгария. Будапеща, 2004, (Simeonova-Hargitaine, 2004); Пейковска, П. Бьлгарските общности в Унгария през XIX-XX век. Миграции и историко-демографрска характеристика. София, 2011, (Peykovska, 2011); Янкова, В. Българите в Унгария - културна памет и наследство. Издание на Републиканското самоуправление на българите в Унгария - Будапеща. София, 2014, (Yankova, 2014); Русков, И. (реА.) Стопански миграции, институции и организационен живот на българите в Аиаспора (Сборник Аоклали от научна конфреренция). Софрия, 2015, (Ruskov, (ed.), 2015); Пенчев, ВА. Българските общности в Средна Европа. Формиране, битуване, илентичности. София, 2017, (Penchev, 2017) и $\Delta \mathrm{p}$.
} 
Благодарение на находчивостта и предприемчивостта си, те успяват не само $А$ р разпространят нови сортове зеленчуци и $А$ внеАрят по-различни, по-ефективни и конкурентноспособни технологии в зеленчукопроизводството, но и Аа оставят своята уникална слеАа в развитието на гражАанските общества в Средна и Запална Европа. В не малко европейски Аьржави, като например Унгария, Чехия, Словакия, Австрия и Ар., $\Delta \mathrm{O}$ Аен Анешен живеят наслеАници на български гралинари-гурбетчии, които не само не губят връзката си с България, но и продьлжават културния обмен межАу нашата и техните страни. Макар големите мащаби на гурбетчийското градинарство $А$ а са отАавна само спомен, това измерение на неговото значение показва, че темата не е загубила своята Аавност и от проекти, като този, за който става Аума, има смисьА.

Инициативата за стартирането на трансграничен проект за културен маршрут пол наАслов "По пьтя на българските гралинари" институционаАно принаАлежи на ИзслеАователския институт на българите в Унгария при Българското републиканско самоуправление в Унгария, който се обърна към Регионален исторически музей - Велико Търново 2 за партньорство. При разработването на сьльржанието, структурата и цялостния план за изпьлнението на проекта, в края на 2015 г. се сорормира и нарочен научно-изследователски екип, вкАючващ освен специалисти от Авете партниращи си институции още и специалисти от Музея на гурбетчийското градинарство в Аясковец и от Шуменския университет „Епископ Константин Преславски“. През 2017 г. като партньори са привлечени и учени от исторически музей „Йожедр Коста“ в граА Сентеш, от С^авянската кателра при СегеАския университет и от Балканския институт при Печкия университет. От края на 2018 г. в екипа се вкАючи и Историческият музей в грал Горна Оряховица (Фиг. 1).

2 Важно е ла се отбележи, че в етнографрския си фонд Регионален исторически музей Велико Търново съхранява богата колекция от снимки, Аокументи, книги, инвентар и различни Аруги материални ценности на градинари гурбетчии. Причина за това е, че великотьрновският край е „изпратил” в странство изключително много хора; че найпродьлжително и най-мащабно е гурбетуването на градинари точно от селища в Тьрновско, Аясковско и Горнооряховско. 


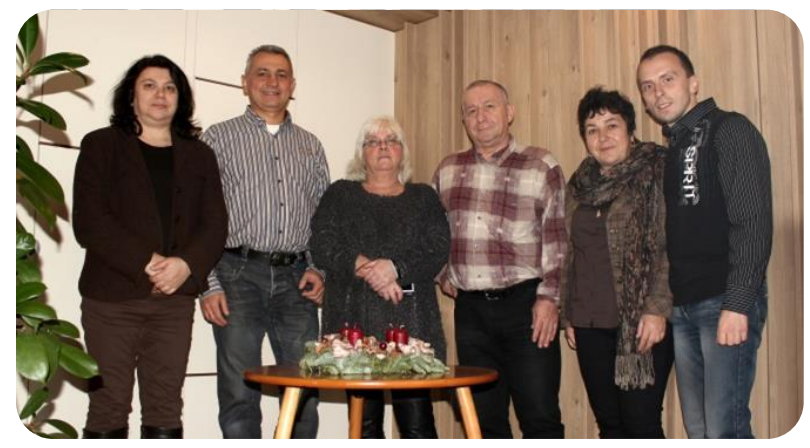

\section{Фиг.1. Научно-изслеАователският екип на проекта „По пътя на българските граАинари" при разработването му}

(Аекември 2015 г., гр. Булапеща)

ВиАно е че още със създаването си проектьт е отворен. Аопьлнително трябва $\Delta а$ се спомене, че и самото му реализиране прелполага привличането на разнообразни научно-изслеАователски, културни и образователни институции и специалисти, от което става ясно, че в него винаги ще има място за още съмишленици, полкрепящи илеята за сполеляне и преживяване на общото културно наслеАство на градинарите-гурбетчии, опазването му като ресурс за устойчиво икономическо и културно развитие, както и вписването му в полето на разнообразната европейска иАентичност.

Всъщност проектьт има за основна залача издирването и събирането на материални и нематериални свидетелства за българското гурбетчийско градинарство, съхраняването на историята на българските градинари-гурбетчии, както и популяризирането и развиването на съзАалените от тях исторически, стопански и културни връзки межАу европейските народи. Работата по тези изслеАователски залачи трябва $\Delta а$ аоведе $А$ постигането на главната цел на проекта, а

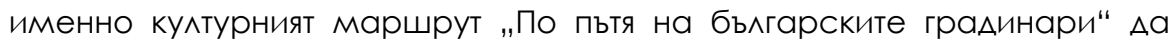
стане част от Европейската програма „Културни маршрути”, т.е. траен и развиващ се във времето научно-изследователски и туристически "Пьт", показващ еАна много интересна, но неАостатьчно позната страна на българското в рамките на общо европейското културноисторическо наслеАство.

От целта и залачите на проекта се вижла, че насоките, които са набелязани в изпьлнението му съвсем не са малко. Освен това те са 
съобразени с и се базират на основните изисквания, установени от Сьвета на Европа за културни маршрути:

- Научноизследователски разработки;

- Подчертаване на паметта, историята и европейското наслеАство;

- Културен и образователен обмен на млали европейци;

- Съвременни културни и артистични практики;

- Културен туризъм и устойчиво културно развитие.

Пьрвата инициатива, с която се Аава и официален старт на проекта през 2016 г. е представянето в България на мобилна Авуезична (на български и унгарски език) изложба със същото заглавие - „По пьтя на българските гралинари".

Тя е създалена по повод 100-годишнината на Аружеството на българите в Унгария, а неин автор е Аиректорьт на Изследователския институт на българите в Унгария г-жа Моника Тютюнкова (фиг.2).
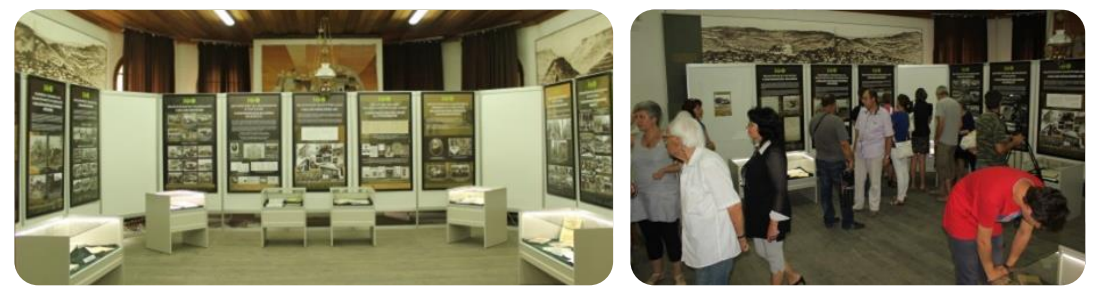

\section{Фиг.2. МобиАна изложба „По пътя на бъмгарските граАинари” в музей „Възражаане и Учреаително събрание"}

(юли-август, 2016 г., гр. Велико Търново)

В основата на изложбата са няколко големи табла, които, чрез много фоотографиии, Аокументални свиАетелства и текст, прослеАяват важни моменти от живота на българските градинари-гурбетчии в Унгария. МежАу тях са пренасянето на унгарска територия на водното колело (Аолапьт) като поливно съорьжение, всекиАневието на градинарите и развитието на градинарските слружения, учредяването на Аружеството на българите в Унгария, построяването на Българския културен Аом там, основаването на българската цьрковна община и на българското училище в Булапеща и лр. Редно е $а$ а се спомене още, че всяко издание на изложбата в Бьлгария се отличаваше със своя специфика - показвани бяха Аопьлнителни експонати от музейни фондове и архиви. На всяко експониране бяха организирани срещи с наслеАници на гралинари-гурбетчии. 
Изложбата „По пьтя на българските гралинари" обиколи не малко селища в страната (Велико Търново, Шумен, Поликраище, Софрия, ПловАив, Смолян и др.), като по този начин не само трасира елин своеобразен културен маршрут, но и провокира не малко хора, свързани по някакъв начин с някогашните градинари-гурбетчии, $\Delta а$ се върнат към спомена за предците си и Аа потьрсят материални свидетелства на паметта, останали им в наследство от тях (Фиг. 3,4$)$.

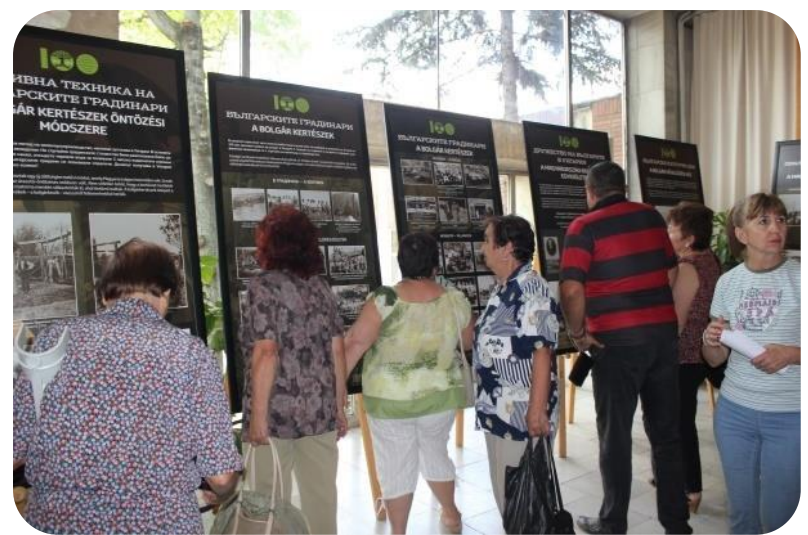

Фиг. 3. Откриване на изложбата „По пътя на бъмгарските граАинари” в Регионална библиотека „Стоян Чимингиров”

(10.09.2016 г., гр. Шумен)

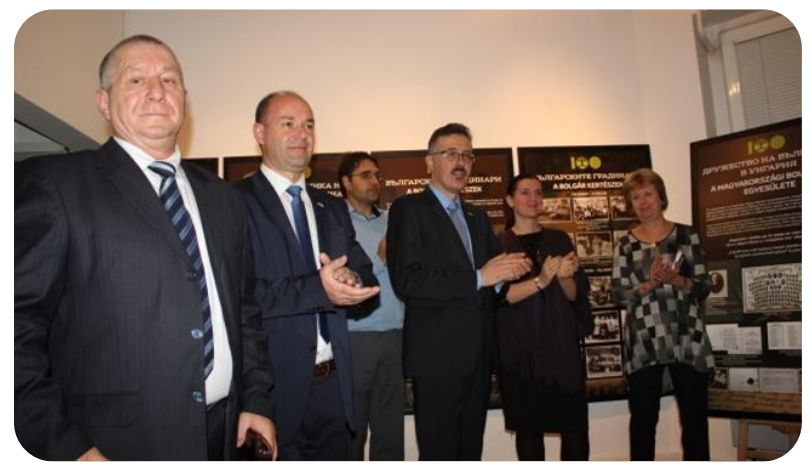

Фиг. 4. Откриване на изложбата „По пътя на българските граАинари” в Унгарския културен институт

(17.11.2016 г., гр. Софияя) 
По този начин се разшириха и се зальлбочиха проучванията в архиви, музейни фондове, библиотеки и Ар.; създадоха се живи човешки контакти; офрормиха се трайни изслеАователски теми.

Като Аруга много успешна инициатива в рамките на проекта трябва Аа се отбележи полготвянето и изАаването на книгата „Колелото на сьлбата". Бъмгарското гурбетчийско градинарство (етнографоски аспекти)".

Неин автор е Аьлгогодишният музеен уредник и сериозен изследовател на тралиционното гурбетчийско градинарство в България А-р Васи^ Мутадров (Фиг. 5).

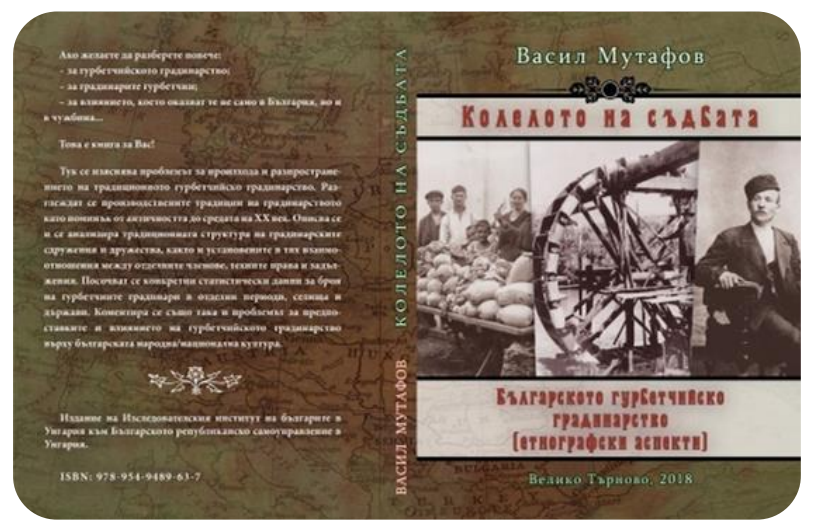

Фиг. 5. Монография на А-р В. Мутафов „Колелото на съАбата" Българско гурбетчийско граАинарство (етнографски аспекти)" 2018 г.

В своето изследване той фокусира погледа си както върху произхода и разпространението на явлението, така и върху влиянето и следата, която българските градинари гурбетчии оставят не само в нашата страна, но и навсякьАе, кьлето са упражнявали своята трудова Аейност.В книгата си авторьт прави полробна историко-етнографрска характеристика на гурбетчийското градинарство, като се разкриват слабо известни страни на коментирания проблем. В нея той разглежАа производствените тралиции на градинарството като поминьк от античността $А$ среАата на XX век. Описва и анализира тралиционната структура на градинарските слружения и Аружества, както и установените в тях взаимоотношения межАу отАелните членове, техните права и зальлжения.Посочва конкретни статистически Аанни за броя на гурбетчиите градинари в отделни периоди, селища и дьржави. 
Коментира също така и проблема за предпоставките и влиянието на гурбетчийското гралинарство върху българската народна/национална култура.За отбелязване е, че премиерно книгата бе представена на 18 октомври 2018 г. в Будапеща в сгралата на Българското самоуправление на ул. „Байза" 44.

Волещ на събитието е предселателят на Българското републиканско самоуправление в Унгария А-р Аанчо Мусев - фракт, който още веАнъж потвържАава сериозната оценка и значимостта не само на труа нал-р Мутафров, но и на целия проект „По пьтя на българските градинари".(Фиг. 6).
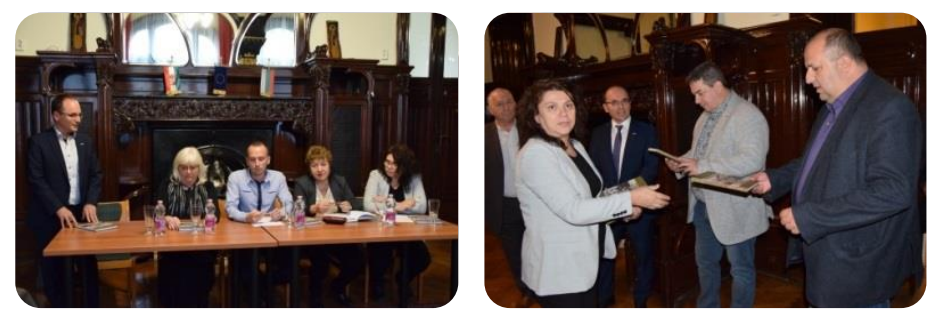

\section{Фиг. 6. ПреАставяне на монографията на А-р Мутафов в БуАапеща}

За България премиерата на „Колелото на съдбата“. Българското гурбетчийско градинарство (етнографоски аспекти)" е реализирана на 21 ноември 2018 г. във Велико Търново - в музей „Вьзраждане и Учредително събрание". (Фиг. 7).
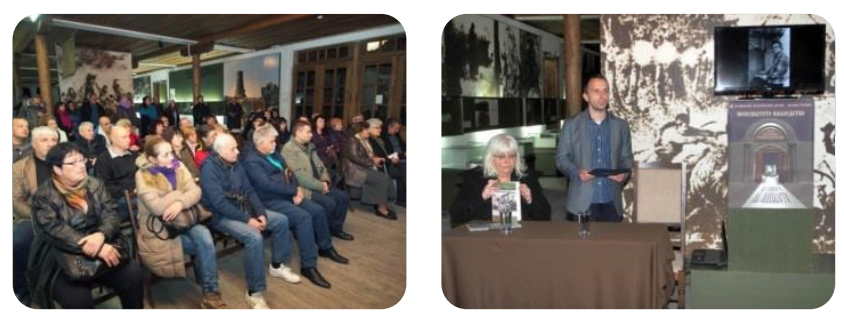

Фиг. 7. ПреАставяне на монографията на А-р Мутафов във Велико Търново

На това представяне гостуваха не само жители и гости на старата столица, но и не малко колеги на А-р Мутафоов. За съжаление, месец преди отпечатването на книгата той напусна този свят, на 74гоАишна възраст. 
Освен следващи представяния на книгата на д-р Васил Мутафов, както и гостувания на мобилната изложба „По пьтя на българските градинари" в страната и чужбина, проектьт има планувани и още инициативи по няколко направления:

1. Натрупване и систематизиране в архив на неизвестни или малко известни фокти от историята на българското гурбетчийско граАинарство в миналото и сега.

2. Подготвяне и издаване на: Сборник с материали от тематична научна конореренция; Аву/триезичен документален албум; Конкретни тематични Аипляни, свързани с градинарството като стопански отрасьл, с градинарската кухня и Ар.; Аокументални и учебни фоимми; 3D изложба и $А$.

3. Изготвяне на културно-образователни програми и сериозни интерактивни образователни игри, насочени предимно към Аеца и м^али хора.

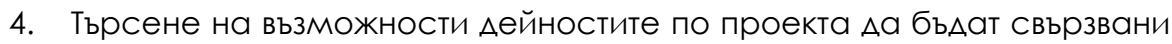
с арт-изяви (орестивали, концерти, пьророрманси) и Аруги утвьрлени културни инициативи по места (празници на селища, изложения, исторически възстановки и т.н.), с цел създаване на непосреАствени и разнообразни контакти и развитие на културния туризъм.

5. Търсене и привличане на още научно-изследователски, културни и образователни институции, свързани с темата на проекта в страни от Запална и Източна Европа, с цел ^ансиране и затвьржАаване на ценността на пътя във всичките му проявления (изслеАователски, образователни, емоционални, икономически), като виА културно наслеАство.

6. Търсене и привличане на частни стопански и нестопански организации (ресторантьори, хотелиери, туристически агенции, туроператори и мр.) с цел съзАаване на ясно определена мрежа от тематично свързани културно-образователни и туристически обекти и/или непрекьснато трасе.

Работата по тези направления би утвьрАила проекта „По пьтя на българските градинари" като трайно развиващ се културен продукт, който изявява споделеното европейско наслеАство, прослеАявайки историята на българските градинари-гурбетчии, техните миграции и разпространението не само на българския опит и Аостижения в градинарството и зеленчукопроизводството, но и обмена на общоевропейски материални и нематериални културни ценности. 
Така „Сьвместната ни работа може да се нарече исторически $\Delta ь \wedge г$ на съмишленици и приятели, защото българските градинаригурбетчии в Унгария са онези хора, които са сьздали безспорно полезни и истински толерантни модели на межАуетническо общуване, за което трябва да сме им благодарни и да почетем постиженията им полобаващо, създавайки и реализирайки успешно този проект."з.

\section{Аитература / References}

Changova-Menihart, P. (1989). Pod slanceto na Ungariya: ocherk za stopanskata deynost na balgarskite gradinari (1720 - 1980) (in Bulgarian). Sofia, Bulgaria, 1989 // [Чангова-Менихарт, П. Пох сльнцето на Унгария: очерк за стопанската Аейност на българските градинари (1720 - 1980). София, 1989].

Ganeva-Raycheva, V. (2004). Balgarite $\vee$ Ungariya - problemi na kulturnata identichnost (in Bulgarian). Sofia, Bulgaria, 2004 // [Ганева-Райчева, В. Българите в Унгария - проблеми на културната илентичност. Сосрия, 2004].

Geshov, Iv. (1888). Nashite gradinasrki druzhestva. In: Periodichesko spisanie na balgarskoto knizhovno druzhestvo (in Bulgarian). year VI, book XXVII, Sredets, Bulgaria, 1888 // [Гешов, Ив. Нашите граАинарски Аружества. - В: Периодическо списание на българското книжовно Аружество. ГоА. VI, КН. XXVII. Срелец, 1888].

Ginchev, Ts. (1887). Nyakolko dumi of istoriyata na nasheto gradinarstvo (bahchovandzhilak) i za uredbata na gradinata. In: Trud (in Bulgarian), book I, Veliko Tarnovo, Bulgaria, 1887 // [Гинчев, Ц. Няколко Ауми от историята на нашето градинарство (бахчованАжильк) и за уредбата на граАината. - В: Труа. Кн. І. Велико Търново, 1887].

Gyurov, Al. (2001). Edinadesetvekovnoto balgarsko prisastvie $\vee$ Ungariya (in Bulgarian). Budapest, Hungary, 2001 // [Гюров, А^. ЕАиналесетвековно българско присьствие в Унгария. Будапеща, 2001].

Penchev, VI. (2017). Balgarskite obshtnosti $\vee$ Sredna Evropa. Formirane, bituvane, identichnosti (in Bulgarian). Sofia, Bulgaria, 2017 // [Пенчев, ВА. Българските общности в Средна Европа. Формиране, битуване, илентичности. Софиия, 2017 и $\Delta$ p.].

3 Из словото на А-р Аанчо Мусев, предселател на Българското републиканско самоуправление в Унгария от 2002 г., преА изследователския екип на трансграничния проект за културен маршрут „По пьтя на българските градинари“, изказано по време на пьрвата работна организационна среща в гр. Булапеща на 10 Аекември 2015 г. 
Peykovska, P. (2011). Balgarskite obshnosti $\vee$ Ungariaya prez XIX-XX vek. Migratsii i istoriko-demografska harakteristika (in Bulgarian). Sofia, Bulgaria, 2011 // [Пейковска, П. Българските общности в Унгария през XIX-XX век. Миграции и историко-демографрска характеристика. Софиия, 2011].

Ruskov, I. (ed.), (2015). Stopanski migracii, institucii i organizacionen zhivot na balgarite $v$ diaspora (Proceedings) (in Bulgarian). Sofia, Bulgaria, 2015 // [Русков, И. (ред.) Стопански миграции, институции и организационен живот на българите в Аиаспора (Сборник Аоклали от научна конореренция). Софрия, 2015].

Simeonova-Hargitaine, P. (2004). Gradinarskata kultura i deynost na balgarskite gradinari $\vee$ Ungariya (in Bulgarian). Budapest, Hungary, 2004 // [СимеоноваХаргитаине, Р. Гралинарската култура и лейност на българските гралинари в Унгария. Будапеща, 2004].

Sirakov, M. (1922). Gradinarite ot Tarnovsko v stranstvo (studia) (in Bulgarian). Veliko Tarnovo, Bulgaria, 1922 // [Сираков, М. Гралинарите от Търновско в странство (студия). В. Търново, 1922].

Yankova, V. (2014). Balgarite $\vee$ Ungariya - kulturna pamet i nasledstvo. Izdanie na Republikanskoto samoupravlenie na balgarite $\vee$ Ungaria - Budapeshta (in Bulgarian). Sofia, Bulgaria, 2014 // [Янкова, В. Българите в Унгария - културна памет и наследство. Издание на Републиканското самоуправление на българите в Унгария - Будапеща. Софиия, 2014]. 
КУАТУРНО-ИСТОРИЧЕСКО НАСАЕАСТВО: ОПАЗВАНЕ, ПРЕАСТАВЯНЕ, АИГИТААИЗАЦИЯ

\section{CULTURAL AND HISTORICAL HERITAGE: PRESERVATION, PRESENTATION, DIGITALIZATION}

Научна пореАица: брой 1(6), гоАина V (2019)

Science series: volume 1(6), year V (2019)

\section{ISSN: 2367-8038}

\section{Релактори \\ Петко Ст. Петков \\ Галина БогАанова \\ Институт по математика и информатика БАН, Бъмгария}

Материалите в сборника са обект на авторско право. Разрешава се безвъзмезАното ползване на техни електронни/ хартиени копия само

за лична употреба или с цеА обучение, при писмено указание за Аипса на търговски намерения и пь^но цитиране на текста от тази

страница.

За копиране пол Аруга орорма, препубликуване или публикуване на сървъри се изисква писмено разрешение и/или зап^ащане.

() Авторски колектив, 2019

Технически реАактори: Николай Ноев, гА. ас. А-р Калина Сотирова-Вълкова, ас. А-р

\author{
Editors \\ Petko St. Petkov \\ Galina Bogdanova \\ Institute of Mathematics and \\ Informatics \\ BAS, Bulgaria
}

This work is subject to copyright. Open and free use of digital/ hard copies of publications is granted only for personal or educational use, while there are written statement for not-commercial intention and full citation of the text of the current page.

For any other reproducing types, re-publishing, photocopying, recording, orany other storage retrieval system/server is required written permission and/or fee.

(C) Authors` Group, 2019

Technical editors:

Nikolay Noev, Assist. Prof. PhD Kalina Sotirova-Valkova, Assist. Prof. $\mathrm{PhD}$ 